\title{
ROUTE OF THE WORLD HERITAGE MONASTERIES IN PORTUGAL AND A DIGITAL TOURISTIC PLATFORM
}

\author{
José R. Mendes ${ }^{1,4}$, Andreia Galvão ${ }^{2,4}$, Ana M. T. Martins ${ }^{3,4}$ \\ ${ }^{1}$ Polytechnic Institute of Tomar, Head of ICT Unit, Estrada da Serra, Quinta do Contador \\ 2300-313 Tomar, Portugal, jmendes@ipt.pt \\ ${ }^{2}$ University Lusíada, Rua da Junqueira, 188 - 198 \\ 1349-001 Lisboa, Portugal, andreiagalvao.map@gmail.com \\ ${ }^{3}$ Department of Civil Engineering and Architecture, University of Beira Interior \\ Calçada Fonte do Lameiro, 6200-001 Covilhã, Portugal, amtfm@ubi.pt \\ ${ }^{4}$ CITAD, Centre of Research in Territory, Architecture and Design \\ Lisbon, Portugal \\ KEYWORDS: Culture, Tourism, ICT, Sustainability, Economy, World Heritage Monasteries, Portugal, digital \\ contents, digital libraries, Europeana, social networks, 3D, virtual reality, augmented virtual reality.
}

\begin{abstract}
We present the ongoing project Route of the World Heritage Monasteries in Portugal and emphasize the planned Digital Touristic Platform. It's been created as a partnership between local authorities where those monasteries are located and with higher education institutions and the National Management Institute of Heritage. It is been financed by European funds over 14,4M€. We describe the strategic plan, the key actions and the model of governance. The role of the Information and Communication Technologies (ICT) on growth and on employment related to cultural heritage and tourism is then approached referring to e-business and digital platforms particularly. We present the results and some new start-up projects as a result of the created synergies. The importance of Heritage Economics with the use of ICT as well as the lessons learned so far are analyzed.
\end{abstract}

Keywords: Culture, Tourism, ICT, Sustainability, World Heritage Monasteries, Portugal, digital contents, digital libraries, Europeana, 3D

\section{PROJECT DESCRIPTION}

The design of the Route of the World Heritage Portuguese Monasteries is the result of a network established between the municipalities of Lisbon, Batalha, Alcobaça and Tomar, and the Polytechnics Institutes of Tomar and Leiria, and the Portuguese Institute for Heritage Management. The route is a world set of unique Cultural Heritage $(\mathrm{CH})$ : The Templar Castle and Convent of Christ in Tomar, the Monasteries of Alcobaça, Batalha and Jerónimos in Lisbon. The total route distance is about $280 \mathrm{~km}$ between these cities and it takes about 2.5 hour's drive by car. The relative positions are shown in Fig. 1. In that map, the Shrine of Fátima is also identified, between Tomar and Batalha.

This set is a thematic and identity anchor of their towns internationally. It reflects the crossroads of major international currents of history, culture, ideas, and spirituality and Intangible Heritage - the Cistercian Order and the Order of the Templars and the Order of Christ and the Portuguese Discoveries.

The creation of the route network aims to increase the scale which encourages the development through the principle of sharing and integration: fewer resources are used, the results are more effective, durable and supportive, so that it creates partnerships with public and private citizens. The use of Information and Communication Technologies (ICT) facilitates and enhances the interactivity between citizens and touristic and cultural products - shortens the distance between consumer and product providers.

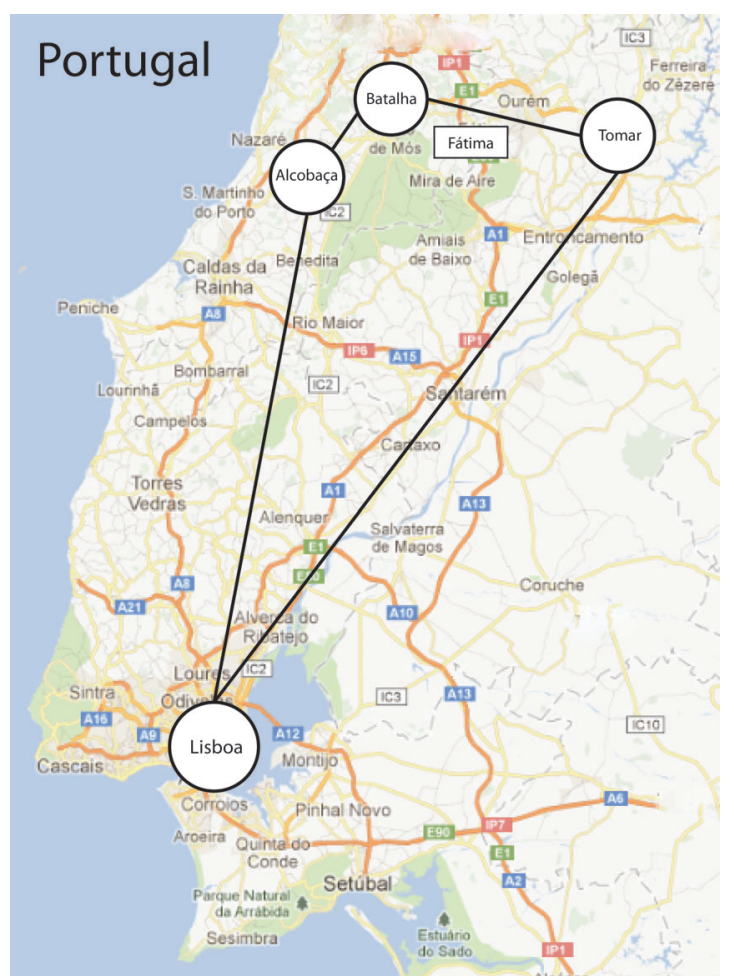

Fig. 1 - Route of World Heritage Monasteries (Portugal) 
The public offering of new services, new applications and new skills associated with management practices and cultural tourism resources resulting from cooperating partners are factors of competitiveness at different levels: research, education, cultural production and cultural promotion and production of digital content.

\subsection{Financing and Strategic Plan}

The project was approved in June 2009, signed the contract in September 2010 and should be completed by 7 September 2014. It was submitted as "Instrument of Cities Policy Urban Networks for Competitiveness and Innovation". The total investment approved is $14,4 \mathrm{M} €$ and $10,7 \mathrm{M} €$ reimbursed by European funds.

The Strategic Plan (Plano Estratégico da Rede de Mosteiros Portugueses Património da Humanidade, 2010) is based on $i$ ) cooperation between cities in potential and vocation issues, reinforcing the differentiation factors, attractiveness, competitiveness and internationalization dynamics ii) consolidation of collective dynamics of urban development focused on innovation and knowledge; promotion of attraction and establishment of innovative activities and qualifying human resources and creative professionals iii) international projection image, resources and activities. It goes through i) create a brand for a cultural tourist product based on qualitative factors (World Heritage) and quantitative factors (visiting 4 monasteries located at most an hour away by car between them) ii) assume a world heritage site as a competitive factor for the locals and global inhabitants, encouraging visitors to learn more about the territory and extend their stay by transforming the resources of urban centers in effective tourism products iii) value added and qualification of the city center providing qualified touristic services, keep boosting the touring and cultural landscape, with an improved visitor experience and qualification of hospitality iv) a new paradigm in knowledge sharing between cities, with cooperative efforts between agencies, multiple levels and spheres of activity around a common purpose: the enhancement of $\mathrm{CH}$ and increase the competitiveness, with Lisbon as an example for the quantum leap is to achieve competitiveness in the touristic cities; $v$ ) competitiveness of the route for enhancing competitiveness and territorial cohesion of the arc route also using the proximity to a major destination for religious tourism in the world, the Shrine of Fátima, vi) Promote partnerships for innovation through the involvement of a multiplicity of network partners: local authorities, institutions of the technological system, scientific and training, private entities and associations vii) qualify human resources and strengthen social skills and cultural agents of the cultural sector to encourage community building through creative cultural productions and promoting actions in the roaming network.

\subsection{Key Actions and Governance}

The key actions are Identity $(8.2 \mathrm{M} €, 38 \%)$ that emphasize the unique and individual traits of the Portuguese: its universality, history and culture; Attractiveness (2,9M€, $35 \%$ ) lies in the historic resources, cultural environment and socio-cultural ambience as a unique experience; Receptivity $(0.5 \mathrm{M} €, 8 \%)$ is a competitive advantage but it presents difficulties to overcome such as poor signaling, inadequate hours of operation and insufficient in multilingual information; Interactivity $(0.2 \mathrm{M} €, 1 \%)$ using the internet through various channels is essential in tourism, culture and business for new opportunities as the relations between consumers and products are changing; Visibility (1.9M€, $13 \%)$ with media and appropriate marketing; Continuity $(0.7 \mathrm{M} €, 5 \%)$ in the perspective of the management of this project after its implementation.

For the governance the principle of partnership cooperation was adopted, looking at the medium to long term by ensuring the participation of all partners, and flexibility in procedures. Supports up into three separate structures: a steering unit with all the institutions involved, a technical support structure and a board of supervision and monitoring. Was also set up a private association, the MPH (Monasteries World Heritage) to manage funding of joint projects from the four municipalities.

\section{ICT, GROWTH, EMPLOYMENT AND CULTURAL HERITAGE ECONOMICS}

The first initiative in the Europe2020' strategy was to create the Digital Agenda 2020 - make every European digital. ICT currently represents $5 \%$ of the European GDP and contributes to about $50 \%$ for competitiveness: is a factor for growth and employment. Digital libraries and the production of digital content and action plans for cultural heritage are promoted by the Digital Agenda.

The $\mathrm{CH}$ seen in a perspective of economic and sustainable development is based on a set of products that should result in a new value chain (Reis \& DeMarco, 2009). Design a prospective integrated, coherent and sustainable for qualifying urban, social and environmental dynamics (Hugues, Hirczak, \& Senil, 2006) are the engine for promoting cultural tourism. In this context, the use of ICT is a crucial factor while preserving (digitizing), disseminating (Internet, Europeana, social networks, virtual reality (Guidi, Frisher, Lucenti, Donno, \& Russo, 2008) and augmented virtual reality, learning and eLearning (Forte, Pescarin, \& Pujol Tost, 2006) and inclusion (Mendes, All Inclusive Digital Town and its Villages, 2000). It also allows to achieve significant economies of scale and greater brand visibility, as well as a qualified and differentiated interpretation in visitation through access to a multidisciplinary digital content and wide use. Also, there are a set of recommendations for the cultural web sites (Commission, CULTUREMAP Mapping and evaluating existing platforms (websites) within the cultural sector aimed at stimulating debate and cross-border exchange of matters concerning European culture, 2010) which are spreading all over the world.

ICT can be very helpful in the study and monitoring the definition of criteria of authenticity and preservation of the cultural value integrity, respecting the cultural and social context in which they enroll. The human memory is an advantage for the development and sustainability to structure a solid foundation for the revival and revitalization of the cultural value. This solid foundation helps to reduce wear and loss of integrity, when demand is excessive (e.g. Pompeii and Jerónimos Monastery (Goral, 2010)). The thematic networks enable flows to redistribute and rebalance the phenomenon of attraction, and the elements with higher uptake capacity contribute to the sustainability of the least known or 


\section{TOURISTIC PLATFORM}

apparently less appealing. The creation of networks of exchange and sharing $\mathrm{CH}$ information through a digital knowledge platform are critical for citizens, enterprises, government and researchers. The management of the shared heritage is central to the different interests and values favoring the integration of different areas of knowledge and creating a new chain value. A common strategy, with multidisciplinary teams, with new responsibilities for management and exploitation of the region should be assumed as a foundation for economic and social sustainability and not as a consequence. The value of these cultural heritage, whether local or global in space (Ortiz, 2007) and, the challenge of employment and qualified training introduces into debate not only the potential of ICT innovation and creativity but also the emergence of a new discipline: Economics of Heritage as an essential pillar of the territory and political communities (Bispo, 2011). The development is inseparable from the strengthening of tourist attractiveness, based on creativity and creation of products such as touring cultural routes (e.g. route of Templar's, route of Cistercians (Martins, Cistercian Architectural Heritage as Cultural Landmarks, 2010) or the route of Jewish Quarters). The Heritage is the people. It is not a closed matter subjected to management with strict rules: the active social life of citizens, the transversal of areas they pass through, the multicultural realities and multiple opportunities are continuously modified. The values and meanings associated to $\mathrm{CH}$ are a socio-cultural subject having new criteria for facing the changing concept of Space-Time. The transformation of economic and social dynamics determine, inevitably, the change of the principles of integrity, authenticity (Alho, Morais, Mendes, \& Galvão, 2010), preservation, enhancement and safeguard of $\mathrm{CH}$.

\subsection{Emergent Tourism Tendencies and eBusiness}

New trends emerge in the tourism and culture business: auto personalization (the consumer draws your product); ebusiness (between consumers, businesses and government) (Commission, ICT and eBusiness in the Tourism Industry, ICT adoption and eBusiness activity in 2006, 2006); thematic segmentation of markets (clusters of excellence); changes in the value chain (the consumer is closer to product); emarketing (instant, customized); interaction (multiple channels of communication via the Internet where the consumer navigates freely).

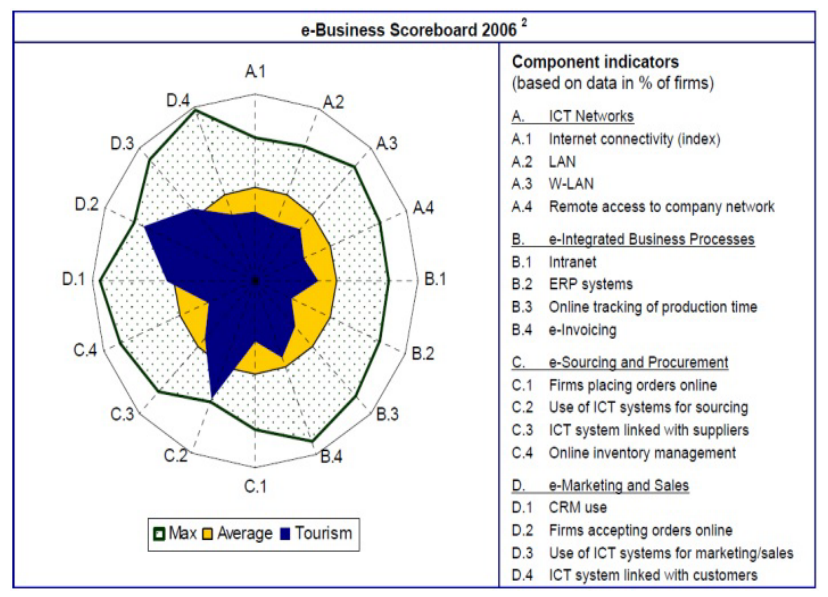

Fig. 2 - eBusiness in Tourism
The ebusiness in tourism is above average in ICT as a resource, management of customers, accept orders online, marketing and sales. On the other hand, is on average in use of Intranet, electronic invoicing and consumer liaison (

Fig. 2).

The interaction is increasingly important for citizens, businesses and government: the provision of new services and new applications allows tourists to negotiate the best conditions for their journey and make visitation as a unique experience in terms of interpretation and enjoyment. ICT enables a noninvasive intervention, preservation and integration into the fruition of $\mathrm{CH}$.

\subsection{Touristic Digital Platform}

An architecture for the digital platform is presented in Fig.3 (Tian, Junping, Zengqi, \& Yingmin, 2010). This is the base model adopted so far for the route of the monasteries (Mendes, Projeto Plataforma Digital - Análise Síntese da arquitetura, serviços e funcionalidades; Rede de Mosteiros Portugueses Património da Humanidade, 2010). As it can be seen we have some access channels (tv, internet terminals), some touristic enterprises and authorities, some layers (presentation, access, service management, business and data resources), some data resources (basic information, knowledge base, media library) and some application services (route planning, public services, multimedia).

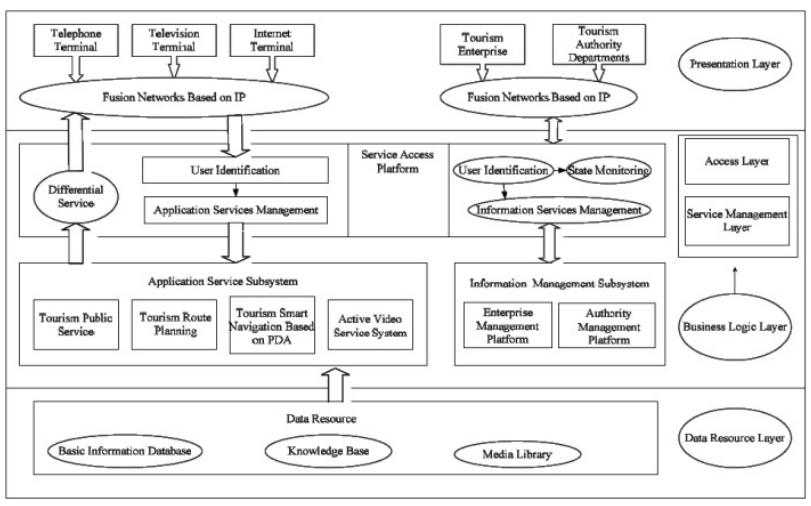

Fig.3 - Digital Platform Model

\section{RESULTS}

The planned investment was $14.4 \mathrm{M} €$ and it has been defined $12.3 \mathrm{M} €$ so far. Until December 31, 2011, had only been approved $4.5 \mathrm{M} €$ and $1.5 \mathrm{M} €$ executed. The financial implementation of the program is $31 \%$ of schedule. Only $42 \%$ of the funds applied for were approved, indicating a low rate of approval by the national structure of management (Relatório de Execução Anual 2011, 2012).

To build infrastructure for the qualification of public spaces in the vicinity of monuments (access roads, parking spaces, reception) are ongoing. Some actions have been developed and animated series programmed (concerts, theater history, colloquia). There are ongoing contests for roadmaps visitation and interpretation and to implement the digital platform. It's already been done some promotional traditional marketing. 
Table 1. Ratio Approved / Programmed (from achievements report) $\mathrm{M} €$

\begin{tabular}{|c|c|c|c|c|c|}
\hline Key Action & Action & Programmed & Submited & Aproved & Aprov/Progr \\
\hline \multirow[t]{2}{*}{$\begin{array}{r}\text { KA1 Identity } \\
(38 \%)\end{array}$} & $\begin{array}{r}\text { A1 Qualifying public } \\
\text { spaces }\end{array}$ & 5,553 & 5,081 & 1,871 & $34,3 \%$ \\
\hline & A2 Events & 2,640 & 2,419 & 0,729 & $27,6 \%$ \\
\hline \multirow[t]{3}{*}{$\begin{array}{r}\text { KA2 } \\
\text { Actractivity } \\
(35 \%)\end{array}$} & $\begin{array}{r}\text { A3 Qualifying cultural } \\
\text { and museological } \\
\text { equipments }\end{array}$ & 1,286 & 0,962 & 0,962 & $74,8 \%$ \\
\hline & $\begin{array}{r}\text { A4 Routes of visiting } \\
\text { and interpreting }\end{array}$ & 1,075 & 0,932 & 0 & $0 \%$ \\
\hline & $\begin{array}{r}\text { A5 Reception to } \\
\text { visitors }\end{array}$ & 0,542 & 0,286 & 0,256 & $47,2 \%$ \\
\hline $\begin{array}{r}\text { KA3 } \\
\text { Receptivity } \\
(8 \%)\end{array}$ & $\begin{array}{r}\text { A6 Qualifying touristic } \\
\text { services }\end{array}$ & 0,548 & 0,548 & 0,205 & $37,4 \%$ \\
\hline $\begin{array}{r}\text { KA4 } \\
\text { Interactivity } \\
(1 \%)\end{array}$ & $\begin{array}{r}\text { A7 Digital Touristic } \\
\text { Platform }\end{array}$ & 0,200 & 0,199 & 0 & $0 \%$ \\
\hline $\begin{array}{r}\text { KA5 Visibility } \\
(13 \%)\end{array}$ & $\begin{array}{l}\text { A8 Marketing, } \\
\text { promotion and } \\
\text { communication }\end{array}$ & 1,909 & 1,470 & 0,481 & $25,1 \%$ \\
\hline $\begin{array}{r}\text { KA6 } \\
\text { Continuity } \\
(5 \%)\end{array}$ & A9 Cooperation & 0,684 & 0,426 & 0 & $0 \%$ \\
\hline TOTAL & & 14,437 & 12,323 & 4,504 & $31,1 \%$ \\
\hline
\end{tabular}

\subsection{Developed Work}

As a Professor, on behalf of the Institute Polytechnic of Tomar (IPT), we are part of the team steering the project. We worked in the design and application for funding the project, in the planning of their implementation, and monitoring of development and implementation.

As Director of the ICT unit of the IPT we lead the team who has participated in the work involving the use of ICT in CH. Within this framework we developed studies and advice to support procurement of enterprises for execution of subprojects, e.g. touristic digital platform and roadmaps for urban visitation.

As for touristic digital platform we adapted to the reality of world's heritage monasteries in Portugal, the already mentioned above: European recommendations for cultural sites including knowledge data bases, elearning, digital libraries and digital contents; the platform architecture proposed by (Tian, Junping, Zengqi, \& Yingmin, 2010) connecting citizens, businesses and government and; the use of new e-business models with features such as happens in customer relationship management, enterprise resource planning and business intelligent applications. This study resulted in a document that was approved by the steering committee towards the project to underpin the specification for the development of touristic digital platform.

As for urban visitation itineraries we promote meetings between the technical teams of the IPT and the Institute Polytechnic of Leiria (IPL), specialists in ICT, Tourism and Culture. These meeting were to define the forms of heritage resources and urban routes visitation. Also, to define what resources in ICT equipment and applications to use on those urban visitation routes. There were defined points of visitation in urban circuits and which data to be collected (text, sound, image and video) from each of those points of visitation. The IPL will develop circuits visitation and data collection in the cities of Alcobaça and Batalha and IPT will develop circuits and data collection in the city of Tomar.

\subsection{Work Planned}

The specifications for the call to implement the touristic digital platform is nearing completion for subsequent approval at a meeting of project steering and later called candidates for execution and implementation of an estimated $€ 0.2$ million sub project.

The data collection for urban circuits visitation will begin in November 2012 with an estimated completion circuits for urban visitation late 2013

Portugal is going through a difficult time economically and are underway by the current government reassessment of all projects funded by Europe. Awaited indications on whether there is any consequence for the remaining funds not yet implemented.

Resulting from synergy, we are organizing a Conference on Jewish Heritage (1st International Conference on Jewish Heritage, science, culture, knowledge) and a Conference on the Philanthropic Heritage (I Conferência Filantropia e Arquitectura 2012 - Periodo 1880-1920. Call for papers).

\subsection{Related new projects from new synergies}

There are some start-up projects resulting from synergies created: the Route of Cistercians Monasteries, the Route of Jewish Quarters, Thousand Years of Wisdom and The Route of Philanthropic Architecture (Galvão \& Mendes, Philantrophy and Archictecture, 2011).

In the Cistercian Route is intended to create a database with the cataloging of this Order assets (Martins, Património Arquitectónico Cisterciense: um contínuo testemunho, 2011) available through the Internet and allowing citizens and researchers to analyze this $\mathrm{CH}$ and its evolution over the centuries. The Route of Jewish Quarters intends to show a Jewish presence in Portugal integrating this knowledge with the network of Jewish Quarters in Spain thus covering the territory of Sepharad. In particular, the Synagogue of Tomar (Schwarz, 1939) is the oldest (Sec XV) preserved in its architectural structure in Portugal, Spain an even in the world. The initiative Thousand Years of Wisdom, aims to apply ICT to the Convent of Christ by creating new products, services and applications (Mendes, Mil Anos de Sabedoria, da idade média ao século XXI, Tecnologias de Informação e Comunicação no Convento de Cristo, 2010). Some of these digital contents are in a 3D format (Mil Anos de Sabedoria, TIC no Convento de Cristo, 2010) revealing the importance of the virtual reality (Guidi, Frisher, Lucenti, Donno, \& Russo, 2008) and augmented virtual reality. The Route of Philanthropic Architecture aims to understand a restricted core under the Heritage contemporary social point of view, in its genesis, function, performance and impact. All produced digital contents (text, sound, photographs, video and 3D) are taking into account to make them available to the Europeana 


\section{TOURISTIC PLATFORM}

by including Dublin core standard metadata. Digital Libraries produced (Mendes, et al., 2009) from these projects will improve services, as well as the quantity and quality of digital contents, and provide access to cultural assets that were previously scattered or not scanned. As a result, a considerable part of our European collective memory will be available online for study, research, creativity, learning, leisure, tourism, culture and business promoting the heritage economics.

\section{CONCLUSIONS}

This project's strategy is still up to date in view of exploiting new add value created from the world $\mathrm{CH}$ (Prud'homme, 2008) new products, services and applications, such as routes, digital contents, e-business and sharing management cultural and touristic resources. It is important to ensure that the strategy is in line with new national policies (Ferreira, 2011) once the Portuguese Government has changed. It is in time to implement the digital knowledge platform for sharing information and start to provide new services and applications. Strengthen partnerships between institutions involved in the project, in particular taking advantage of the vast knowledge of Lisbon, is fundamental to the assertion of the network. Despite the criteria of funding eligibility does not allow the inclusion of private sector (e.g. hotels, restaurants) it is important to foster partnerships so that each one contributes with its resources and skills. There is therefore a total divorce between the project and the private sector that has to be filled to increase the impact on tourism, cultural services and products. The Shrine of Fátima $(5,8 \mathrm{M}$ visitors per year) is important for the project despite not being directly integrated in the network shares.

In operational terms it is recommended to increase the efficiency of the national approval funds even knowing the complexity of documentation and procedures to justify the costs and the diversity of types of projects submitted. Of fundamental importance is the installation and ownership of the board of supervising and monitoring - there is a lack of monitoring the project development.

It is agreed that financial and operational reprogramming is a critical factor to increase the overall effectiveness and make adjustments that aim to continue the strategy in the medium to long term 2014-2020. The competitive advantages in building partnerships, networks and sub networks or other thematic structures is a way to defend the heritage and territory, providing sustainability and increasing the competitiveness of communities and their local business (Galvão, Redes, rotas e parcerias estruturantes - o caso da Rota dos Mosteiros Portugueses Património da Humanidade, 2009). Also, it reduces inequalities and creates new spaces and opportunities.

An important result of the information society revolution, using ICT, is that of make it possible scaling a new ubiquitous space-time relation: anywhere, anytime. Today, although we are global citizens, we are even more local citizens. Our emotional feeling go increasingly to transnational (Canclini, 1994) issues of symbolic values (e.g. Judaism, Templar's, Cistercians). These new communities use ICT to interact in a more personal, experiential and emotional way. Social networks play a key role in this context: they are the tool of the 21 th century for numerous fields of application and socialization as the interdisciplinary scientific and technical applicability. At this stage of transition between old and new $\mathrm{CH}$ conservation policy framework for an effective participation and enjoyment of the citizens who changed the shape of the demand and supply, forcing a reset communication strategies on e-business. The citizens use the Internet to build their product, build their visitation schedule, establishing from the place of their origin to an interactive relationship with the territory of destination and tourist services deployed there. This accessibility is a key factor at the moment of decisive choice, being one of the key trends emerging tourist consumption. Also the use of ICT during the visitation is critical to provide a unique experience. Develop digital platforms where citizens, businesses and government may share information and knowledge is an essential foundation for economic heritage.

In summary there is a need for greater coordination among agencies, greater participation of the business, higher activity and leadership of the national governance, increase efficiency in the coordination between the agencies involved and the effect of monitoring actions. The role of ICT is fundamental to the $\mathrm{CH}$ in its closure to citizens and encouraging networks between public bodies, businesses and citizens.

\section{References}

(n.d.). Retrieved 08 15, 2012, from 1st International Conference on Jewish Heritage, science, culture, knowledge: http://www.aast-conf.ipt.pt/?lng=EN

Mil Anos de Sabedoria, TIC no Convento de Cristo. (2010). (Instituto Politécnico de Tomar) Obtido em 20 de 05 de 2012, de http://templar.ipt.pt/ convento/pt/index.php?s=atalho\&id $=37$

(2010). Plano Estratégico da Rede de Mosteiros Portugueses Património da Humanidade. Rede de Mosteiros Portugueses Património da Humanidade.

(2012). Relatório de Execução Anual 2011. Rede de Mosteiros Portugueses Património da Humanidade.

Alho, C., Morais, A., Mendes, J. R., \& Galvão, A. (2010). Authenticity Criteria in Conservation of Historic Buildings. Cib2010 World Conference, Building a Better World. Salford, UK.

Bispo, M. N. (2011). Políticas Públicas e o Património Histórico: das primeiras ações a economia da cultura. Contemporãnea, $I X(\mathrm{~N} 1)$, Ed.17.

Canclini, N. G. (1994). O Património Cultural e a construção imaginária do nacional. (R. d. IPHAN, Ed.) Revista do Património Histórico e Artistico, IPHAN, $n^{\circ} 23$, Rio de Janeiro.

Commission, E. (2006). ICT and eBusiness in the Tourism Industry, ICT adoption and eBusiness activity in 2006. Bonn, Germany: Empirica GmbH.

Commission, E. (2010). CULTUREMAP Mapping and evaluating existing platforms (websites) within the cultural sector aimed at stimulating debate and crossborder exchange of matters concerning European culture. Germany: Werner B. Korte, Empirica GmbH. 
Ferreira, T. (2011). Turismo Cultural - Património e Economia. I Congresso Internacional da Rota do Românico. Lisboa.

Forte, M., Pescarin, S., \& Pujol Tost, L. (2006). VR applications, new devices and museums: public's feedback and learning. A preliminary report. In $\mathrm{M}$. Ioannides, D. Arnold, F. Niccolucci, \& K. Mania (Edits.). VAST.

Galvão, A. (2009). Redes, rotas e parcerias estruturantes - o caso da Rota dos Mosteiros Portugueses Património da Humanidade. Forum da Carta Europeia de Abadias e Sítios Cistercienses. Alcobaça, Portugal.

Galvão, A., \& Mendes, J. (2011). Philantrophy and Archictecture. SAVE Save Heritage. Capri, Italia.

Goral, A. (2010). Research on Cultural Tourism development in sacral and spiritual sites from UNESCO World Heritage List. In Heritage 2010 - Heritage and Sustainable Development (Vol. I, pp. 405-414). Green Lines.

Guidi, G., Frisher, B., Lucenti, I., \& etal. (2008). Virtualizing ancient imperial Rome: from Gismondi's physical model to a new virtual reality application. International Journal of Digital Culture and Electronic Tourism, 240-252.

Hugues, F., Hirczak, M., \& Senil, N. (2006). Territoire et patrimoine: la co-construction d'une dynamique et de ses ressources. 683-700.

I Conferência Filantropia e Arquitectura 2012 - Periodo 1880-1920. Call for papers. (n.d.). Retrieved 08 15, 2012, from Ministério da Cultura, Igespar: http://www.igespar.pt/pt/agenda/15/2541/

Martins, A. M. (2010). Cistercian Architectural Heritage as Cultural Landmarks. In Heritage 2010 - Heritage and Sustainable Development (Vol. II, pp. 1023-1034). Green Lines.

Martins, A. M. (2011). Património Arquitectónico Cisterciense: um contínuo testemunho. In Actas do Simpósio Património em Construção (pp. 25-32). Lisboa: LNEC.

Mendes, J. R. (2000). All Inclusive Digital Town and its Villages. In B. a. Stanford Smith (Ed.), E-business Key Issues, Applications and Technologies. IOS Press.

Mendes, J. R. (2010). Mil Anos de Sabedoria, da idade média ao século XXI, Tecnologias de Informação $e$ Comunicação no Convento de Cristo. Tomar, Portugal: Instituto Politécnico de Tomar.

Mendes, J. R. (2010). Projeto Plataforma Digital - Análise Sintese da arquitetura, serviços e funcionalidades; Rede de Mosteiros Portugueses Património da Humanidade. Tomar, Portugal: Instituto Politécnico de Tomar.

Mendes, J. R., Galvão, A., Caetano, I., Marques, C., Campos, R., Silva, V. G., et al. (2009). World Heritage Digital Library in Portugal: The Convent of the Order of Christ and the Castle of the Order of the Temple. In P. Cunningham, \& M. Cunningham (Ed.), eChallenges e2009. Istambul, Turkey: Dublin: IIMC International Information Management Corporation.

Ortiz, R. (2007). Mundialização e Cultura. São Paulo: Editora Brasiliense.

Prud'homme, R. (2008). Les impacts socio-économiques de l'inscription d'un site sur la liste du patrimoine mondial: trois études.

Reis, A. C., \& DeMarco, K. (2009). Economia da Cultura: ideias e vivências . Rio de Janeiro, Brasil: Publit.

Schwarz, S. (1939). Museo Luso Hebraico em Tomar projecto de organização de um museu. Lisboa: Gráfica Santelmo.
Tian, G., Junping, D., Zengqi, S., \& Yingmin, J. (2010). Digital Tourism Integrated Service System Realization. In IEEE (Ed.), Digital Tourism Integrated Service System Realization, IEEE, (pp. 232-237). 